\title{
NOVEMBER 1961
}

\section{INTERNATIONAL REVIEW}

\author{
OF THE
}

\section{RED CROSS}

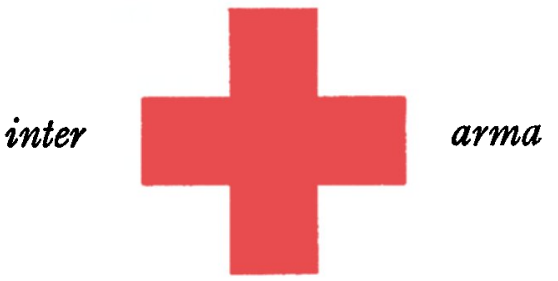

caritas

INTERNATIONAL COMMITTEE OF THE RED CROSS GENEVA 


\section{INTERNATIONAL COMMITTEE OF THE RED CROSS}

LEOPOLD BOISSIER, Doctor of Laws, Honorary Professor at the University of Geneva, former Secretary-General to the Inter-Parliamentary Union, President (member since 1946)

JACQUES CHENEVIERE, Hon. Doctor of Literature, Honorary Vice-President (1919)

CARL J. BURCKHARDT, Doctor of Philosophy, former Swiss Minister to France (1933)

MARTIN BODMER, Hon. Doctor of Philosophy, Vice-President (1940)

ERNEST GLOOR, Doctor of Medicine, Vice-President (1945)

PAUL RUEGGER, former Swiss Minister to Italy and the United Kingdom, Member of the Permanent Court of Arbitration (1948), on leave

RODOLFO OLGIATI, Hon. Doctor of Medicine, former Director of the Don Suisse (1949)

MARGUERITE VAN BERCHEM, former Head of Section, Central Prisoners of War Agency (1951)

FREDERIC SIORDET, Lawyer, Counsellor of the International Committee of the Red Cross from 1943 to 1951 (1951)

GUILLAUME BORDIER, Certificated Engineer E.P.F., M.B.A. Harvard, Banker (1955)

ADOLPHE FRANCESCHETTI, Doctor of Medicine, Professor of clinical ophthalmology at Geneva University (1958)

HANS BACHMANN, Doctor of Laws, Assistant Secretary-General to the International Committee of the Red Cross from 1944 to 1946 (1958)

JACQUES FREYMOND, Doctor of Literature, Director of the Graduate Institute of International Studies, Professor at the University of Geneva (1959)

DIETRICH SCHINDLER, Doctor of Laws (1961)

SAMUEL GONARD, Colonel Commandant of an Army Corps, former Professor at the Federal Polytechnical School (1961)

HANS MEULI, Doctor of Medicine, Brigade Colonel, former Director of the Swiss Army Medical Service (1961)

Honorary members:

Miss LUCIE ODIER, Honorary Vice-President; Messrs, FREDÉRIC BARBEY and Paul CARRY, Miss SUZANNE FERRIËRE, Mrs. R. M. FRICK-CRAMER, Messrs. EDOUARD de HALLER, Rodolphe de HALLER, PAUL LOGOZ, ALFREDO VANNOTTI, ADOLF VISCHER.

Direction: ROGER GALLOPIN, Doctor of Laws, Executive Director JEAN S. PICTET, Doctor of Laws, Director for General Affairs EDOUARD DE BONDELI, Financial and Administrative Director CLAUDE PILLOUD, Assistant-Director for General Affairs 


\section{INTERNATIONAL REVIEW OF THE RED CROSS}

FIRST YEAR - No. 8

NOVEMBER 1961

\section{CONTENTS}

The Metings of the International Red Cross in Prague . . . $\quad \begin{array}{ll}\text { Page } \\ 415\end{array}$

INTERNATIONAL COMMITTEE OF THE RED CROSS

News Items . . . . . . . . . . . . . . . . . . . . . . . . . 423

The reuniting of families . . . . . . . . . . . . . . . . 431

Annual Report of the International Committee . . . . . . . . . 433

Resignation . . . . . . . . . . . . . . . . . . . 442

Mr. Carl Burckhardt receives the Gold Medal of the ICRC . . . 444

NEWS OF NATIONAL SOCIETIES

Philippines .................. . . 448

U.S.S.R. . . . . . . . . . . . . . . . 450

\section{MISCELLANEOUS}

23rd session of the International Office of Military Medicine Documentation.

BOOKS

A GLANCE THROUGH THE REVIEWS 


\section{FRENCH EDITION OF THE REVIEW}

The French edition of this Review is issued every month under the title of Revue internationale de la Croix-Rouge. It is, in principle, identical with the English edition and may be obtained under the same conditions.

\section{SUPPLEMENTS TO THE REVIEW}

\section{SPANISH}

Las reuniones de la Cruz Roja internacional en Praga. - Informaciones del mundo entero.

\section{GERMAN}

Die Versammlungen des Internationalen Roten Kreuzes in Prag. Nachrichten aus Nah und Fern.

THE

\section{INTERNATIONAL REVIEW OF THE RED CROSS}

is published each month by the International Committee of the Red Cross

7, Avenue de la Paix, Geneva, Switzerland Postal Cheque No. I. 1767

Annual subscription : Sw. fr. 20.- Single copies Sw. fr. 2.-

Editor: JEAN-G. LOSSIER 